\title{
Pelarian Masalah Remaja Pada Minuman Alkohol
}

Ferika Kurniawati. Muhammad Ali Sodik

IIK STRADA INDONESIA

ferikakurniawati0063@gmail.com, alisodik2012@gmail.com

\begin{abstract}
Abstrak
Resiliensi remaja yang belum memadai sehingga kesulitan menghadapi masalah cenderung mencari pelarian dan tidak mau menghadapi masalah cenderung menghilangkn masalahnya dengan minuman keras atau minuman alkohol

Alkohol dalam kehidupan manusia mempunyai fungsi ganda yang saling bertentangan. Disatu sisi alkohol merupakan suatu zat yang dapat membantu umat manusia Akan tetapi disisi alkohol dapat dijadikan minuman yang dapat menjadi boomerang yang sangat membahayakan terutama untuk remaja. (Arifin, A. (2020). Pola Asuh Pada Pengguna Alkohol Di Kalangan Remaja. Naskah Publikasi Program Studi Psikologi.)
\end{abstract}

\section{Latar Belakang}

Masa remaja adalah masa transisi atau peralihan dari masa kanak-kanak menuju masa dewasa yang ditandai dengan adanya perubahan aspek fisik, psikis dan psikososial. Masa remaja dimulai dari usia 13 tahun sampai usia 21tahun(Muhammad, 2011).

Semenjak terjadi perubahan fisiologis,kondisi emosi-sosial mengalami perubahan yangdrastis. Pada masa ini, kemungkinan remaja melakukan perilaku menyimpang sangatlah besar. Salah satunya adalah perilaku mengkonsumsi alkohol, karena bagi remaja mengkonsumsi alkohol adalah hal yang lumrah,baik itu untuk meningkatkan kesan keren dan terlihat seperti macho. Alkohol merupakan zat yang dapat mempengaruhi kondisi fisik dan mental, zat yang dapat membuat merasa santai dan senang namun dapat berakibat masalah kesehatan yang serius (Ayudhitya dan Inggriani,2012

Penyalahgunaan alkohol sudah sangat marak, mulai dari remaja hingga orang dewasa. Padahal dalam hal ini remaja merupakan agent of changeyang diharapkan sebagai penerus bangsa(Irmayanti dan Asyanti, 2015).

Penyalahgunaan minuman alkohol oleh remaja sebagai pelarian diri dari mengatasi masalah-masalahnya memang terdengar sangat memprihatinkan,karena tidak seharusnya remaja merusak dirinya dengan menyalahgunakan minuman alkohol. Bahkan tidak sedikit remaja yang meninggal karena over dosis alkohol.Namun hal itu tidak menjadikan remaja penyalahgunaan minuman alkohol menjadi jera, justru setiap tahunnya remaja penyalahgunaan minuma alkohol semakinmeningkat.

Jumlah pecandu minuman keras pada usia remaja di Indonesia mengalami peningkatan pada usia 10-14 sudah ada yang mengonsumsi alkohol sebanyak 0,3 persen.Pada usia 15-19, peminum alkohol mencapai 3,7 persen, dan pada usia 20-24 jumlahnya kembali naik yaitu 6,4 persen. 


\section{Kasus / Masalah}

Setiap orang memiliki kebutuhan untuk mendapat Penerimaan dan penghargaan dari orang lain. Semakin kebutuhan ini tidak dipenuhi maka semakin kuat Keingginan individu tersebut untuk memuaskan kebutuhan ini dengan cara apapun. Penggunaan minuman beralkohol ini diyakini remaja memiliki nilai sosial yang tinggi sehingga dengan menggunakan minuman beralkohol tersebut dapat membuat remaja memiliki penilaian dan penerimaan yang tinggi dari teman-temannya dan menganggap tindakan penggunaan alkohol menjadi jalan keluar bagi persoalan remaja Tersebut dari sinilah pemahaman remaja yang salah yang membuat Populasi seorang pecandu minuman Keras selalu meningkat setiap tahunnya.

Miras Yang diedarkan adalah miras yang Mengandung metanol dan tersangka memproduksinya hingga 200 botol Perhari, yang pastinya bersifat ilegal dan tak ada jaminan dari Dinas Kesehatan dan BPOM yang Menjamin terkait keamanan dan Kualitas mutu dari miras ilegal apabila Dikonsumsi untuk diketahui perizinan Dan peredaran miras yang Mengandung alkohol itu telah diatur Dalam UU Kesehatan dan Peraturan BPOM dan Instasi terkait termasuk Otoritas Peraturan Pemerintahan Daerah (Perda) tentang kebijakan mengatur peredaran dan membatasi mengonsumsi minuman haram tersebut. Banyaknya miras oplosan yang beredar membuat peningkatan Pengonsumsi di setiap tahunnya dan berdampak buruk pada kesehatan hingga meninggal dunia.

\section{Tinjauan Pustaka}

\section{- Pengertian Alkohol}

Minuman beralkohol merupakan salah satu jenis zat adiktif yang penyalahgunaannya menimbulkan dampak yang serius pada kesehatan masyarakat dan masalah sosial. Menurut Peraturan Menteri Pedagangan No. 20 Tahun 2014 tentang Pengendalian dan Pengawasan terhadap Pengadaan, Peredaran, dan Penjualan minuman beralkohol, pengertian minuman beralkohol adalah minuman yang mengandung etanol atau etil alkohol $(\mathrm{C} 2 \mathrm{H} 5 \mathrm{OH})$ yang diproses dari bahan hasil pertanian yang mengandung karbohidrat dengan cara fermentasi dan destilasi atau fermentasi tanpa destilasi. Berdasarkan Ketentuan Standar Industri Indonesia (SII) dari Kementerian Perindustrian RI, minuman berkadar alkohol di bawah 20\% tidak tergolong minuman Keras tetapi juga bukan minuman ringan. Sedangkan Dalam Peraturan Kementerian Kesehatan No. 86/Men.Kes/Per/IV/1977 tanggal 29 April 1977 yang mengatur produksi dan peredaran minuman keras, yang dimaksud dengan minuman keras adalah Semua jenis minuman beralkohol tetapi bukan obat dan meliputi tiga golongan, yaitu:

- Golongan A, dengan kadar etanol 1 sampai Dengan 5\%.

- Golongan B, dengan kadar etanol dari 5 sampai Dengan $20 \%$.

- Golongan C, dengan kadar etanol lebih dari 20 Sampai dengan 55\%.Secara umum, mengonsumsi minum

\section{- Penyebab Seseorang Minum Alkohol}

Ada banyak alasan yang dikemukakan orang mengapa mereka minum alkohol, yakni:

a. Untuk mengatasi rasa sedih dan batin yang tertekan;

b. Untuk melenyapkan rasa tidak aman terhadap dirinya;

c. Untuk melenyapkan rasa rendah diri; 

d. Untuk mencapai tingkat kelegaan yang santai;
e. Untuk melarikan diri dari alam yang nyata.

\section{- Penyebab lain yang dapat menimbulkan seseorang minum alcohol adalah :}

A. Akibat rendahnya tingkat pendidikan Dan ekonomi mayarakat Akibat rendahnya Tingkat pendidikan dan ekonomi Mayarakat maka banyak dari para remaja Dan orang dewasa menganggur dan tidak Ada kegiatan, mereka lebih memilih untuk Berkumpul dengan sesamanya, berjudi, Sambil ditemani minum minuman keras Tentunya.

\section{B. Kebudayaan dan Latar Belakang}

Kehidupan salah satu faktor yang mendorong berkembangnya perilaku minum minuman beralkohol adalah kebudayaan serta latar belakang kehidupan seseorang (Garry R.Collins, 2000).Orang yang pada masa Kecilnya bergaul bersama dengan Pemabuk tentu akan cinderung untuk menjadi pemabuk juga. Hal tersebut karena dalam lingkungan sosial, seseorang cinderung untuk berusaha diterima olah kelompok untuk sosialnya dengan cara mengikuti perilaku Dan gaya hidup mereka.

C. Tidak Adanya Peran Orang Tua dan Tokoh Masyarakat Sebagai kontrol Sosial Masalah yang terjadi adalah banyaknya orang Tua yang bukannya memberikan Contoh baik, mereka malah minum Minuman keras di depan anak-anak tanpa Memikirkan dampak yang akan timbul. Anak-anak yang menyaksikan orang tua Mereka minum mendapatkan nilai bahwa Seakan-akan minum minuman keras itu Adalah sesuatu yang wajar sehingga Mereka cenderung berprilaku yang sama Dengan orang tua mereka.

\section{- Dampak Negatif dari Minuman Alkohol}

Efek yang ditimbulkan setelah Mengkonsumsi alkohol dapat dirasakan Segera dalam waktu beberapa menit saja, tetapi efeknya berbeda-beda, tergantung dari Jumlah / kadar alkohol yang dikonsumsi. Semua perasaan itu akan berangsur angsur menghilang dalam waktu 4 sampai 6 jam. Setelah itu kita akan merasa sangat Lelah dan tertekan. Kadang-kadang wlkohol digunakan dengan kombinasi obat - obatan berbahaya lainnya, sehingga efeknya jadi berlipat ganda. Bila ini terjadi, efek keracunan dari penggunaan kombinasi akan lebih buruk lagi dan kemungkinan mengalami over dosis akan lebih besar.

Bila dikonsumsi berlebihan, minuman beralkohol dapat menimbulkan ganggguan mental organik (GMO), yaitu gangguan dalam fungsi berpikir, merasakan, dan berprilaku. Timbulnya GMO itu disebabkan reaksi langsung alkohol pada sel-sel saraf pusat. Mereka Yang terkena GMO biasanya mengalami perubahan perilaku, seperti misalnya ingin berkelahi atau melakukan tindakan kekerasan lainnya, tidak mampu menilai realitas, terganggu fungsi sosialnya, dan terganggu pekerjaannya. Perubahan fisiologis juga terjadi, seperti cara berjalan yang tidak mantap, muka merah, atau mata juling. Perubahan psikologis yang dialami oleh konsumen misalnya mudah tersinggung, bicara ngawur, atau kehilangan konsentrasi (Anonimity B).

\section{- Kebiasaan minum minuman beralkohol dapat mengakibatkan:}

a. Terhambatnya proses penyerapan zat gizi,

b. Hilangnya zat-zat gizi yang penting, Meskipun orang tersebut mengkonsumsi makanan bergizi dalam jumlah yang cukup

c. Penyakit gangguan hati, kerusakan saraf otak dan jaringan,

d. Di samping itu, minum minuman beralkohol dapat menyebabkan ketagihan dan kehilangan kendali diri. Hal ini dapat menjadi faktor pencetus ke arah tindak kriminal. 


\section{- Pembahasan}

Minuman keras biasa juga Disebut sebagai minuman suling atau Minuman beralkohol yang didapatkan Dari hasil penyulingan. Minuman dari Hasil penyulingan tersebut Mengandung etanol (C2H5OH). Etanol bisa didapatkan dari hasil Fermentasi buah,sayur,dan biji-bijian.

Minol identik dengan produk-produk Seperti anggur/wine, whiskey, vodka,Champagne, abshinte dan sebagainya.

\section{-Faktor - faktor paling berpengaruh adalah}

\section{Faktor Individu}

Rasa ingin tahu adalah kebutuhan Setiap individu yang berasal dari Dalam dirinya, terutama bagi generasi Muda dimana salah satu sifatnya Adalah ingin mencoba hal-hal yang Baru. Rasa ingin tahu terhadap Minuman keras yang oleh mereka Dianggap sebagai sesuatu yang baru Dan kemudian mencobanya, akibat Ingin tahu itulah akhirnya menjadi Pengkonsumsi tetap.

2. Faktor Keluarga

Banyak pengkonsumsi minminuman Keras yang berasal dari keluarga yang Tidak harmonis. Keluarga seharusnya Menjadi wadah untuk menikmati Kebahagiaan dan

3. Faktor Lingkungan

Faktor lingkungan juga sering Membuat pengkonsumsi minuman Keras bertambah, karena lingkungan Yang kurang baik selalu memberikan Kesempatan bagi mereka untuk Mengenal sesuatu yang buruk seperti minuman keras.Sikap seperti itulah Yang menyebabkan anak ikut-ikutan. Awalnya hanya satu orang yang Mengkonsumsi, kemudian semuanya Menjadi pengkonsumsi.

\section{Faktor Agama}

Pendidikan agama merupakan Pendidikan yang utama yang sangat Dibutuhkan bagi anak, dimana hal Tersebut secara langsung berpengaruh Terhadap perilaku dan perkembangan Anak. Pendidikan beragama pada anak Merupakan awal pembentukan Kepribadian, baik atau buruk Kepribadian anak tergantung pada Orang tua serta lingkungan yang Mengasuhnya.Jika agama atau iman Seseorang kuat maka tidak akan Mudah bagi oranglain uuntuk Mempengaruhinya, karena dia Memiliki keyakinan yang kuat Terhadap Tuhannya, tapi jika imannya Lemah sangat mudah bagi orang untuk mempengaruhinya.

\section{Faktor Pendidikan}

Pendidikan adalah hal yang sangat Penting bagi sebuah bangsa. Karena Perkembangan dan kemajuan suatu Bangsa dapat diukur melalui tingkat Dan kualitas pendidikan serta tingkat Kualitas Sumber Daya Manusia (SDM). Pendidikan yang baik pada Seseorang sangat mempengaruhi cara Berpikir, dia tahu benar mana yang Baik dan mana yang buruk.

\section{- Kesimpulan}

Kasus penyalahgunaan Minuman keras yang terjadi di Kalangan remaja akhir-akhir ini Semakin memprihatinkan. Banyak Sekali remaja yang masih di bawah Umur mengkonsumsi minuman keras Tersebut.Sebagian besar remaja menggunakan Minuman keras (alkohol) tersebut Untuk menyelesaikan masalahnya, Mereka berpikir dengan Menggunakan minuman itu akan Sedikit meringankan pikiran. Dapat Disimpulkan bahwa remaja yang Mabuk-mabukan karena termotivasi Beban pikiran dan rasa frustasi yang Selama ini mereka rasakan, oleh Karena itu mereka mencari pelarian Dengan cara mabuk. Bagi mereka Mabuk adalah cara untuk Menyelesaikan dan menghilangkan masalah dan beban pikiran. 


\section{-Daftar Pustaka}

Nataraya, A. D., Nurrohmah, A., \& Mustikasari, I. (2020). EDUKASI FAKTOR PENYEBAB DAN DAMPAK PENYALAHGUNAAN NAPZA PADA REMAJA (Doctoral dissertation, UNIVERSITAS'AISYIYAH SURAKARTA).

Maula, L. K., \& Yuniastuti, A. (2017). Analisis faktor yang mempengaruhi penyalahgunaan dan adiksi alkohol pada remaja di Kabupaten Pati. Public health perspective journal, 2(2).

https://m.liputan6.com/amp/4506391/angka-konsumsi-alkohol-asia-tenggara-meningkat34-persen-bagaimana-di-indonesia

Prasetya, G. A. U. (2021). Dampak mengonsumsi alkohol dan bahaya merokok.

Setyani, A. T., \& Sodik, M. A. (2018). Pengaruh Merokok Bagi Remaja Terhadap Perilaku dan Pergaulan Sehari-hari.

Ningsih, T. W. (2019). Penyalahgunaan Minuman Beralkohol Dalam Lingkup Remaja. 